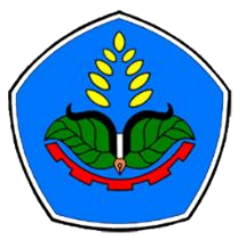

AGROPROSS

National Conference

Proceedings of Agriculture

\section{Proceedings: \\ Peran Teaching Factory Di Perguruan Tinggi Vokasi Dalam Mendukung Ketahanan Pangan Pada Era New Normal}

Tempat : Politeknik Negeri Jember

Tanggal : 8-9 Juli 2020

\section{Publisher:}

Agropross, National Conference Proceedings of Agriculture

ISBN : 978-623-94036-6-9

DOI : 10.25047 /agropross.2020.38

\title{
Kajian Budidaya Jagung (Zea mays L.) Pola "OpSiTongTif"
}

\section{Author(s): Budiono ${ }^{(1) *}$}

(1) Balai Besar Pelatihan Pertanian Binuang

* Corresponding author: insanmadanitlogorejo@yahoo.com

\section{ABSTRACT}

This study tries to implement the concepts of nutrition optimization, pollination, crop design, and market harmonization. This widya study discusses the management of nutrition management, optimization of cob and pollination, management of planting design and the realization of a healthy and harmonious market. Data was collected from primary data (the results of preliminary research into the first to the sixth research) and secondary data. Primary data were obtained from the results of study 1 (synchronization of pollination time in planting different time corn.) To the 6th study (optimization of quality and stabilization of production). Secondary data is supported from data from journals, proceedings, scientific papers and text books on corn cultivation, nutrition, PGR, pollination and plant characteristics of Class Greamineae. The data in the 7th study were metode descriptively by the growth and development cycle of maize at different planting times, ages 1, 2 to 3 weeks. Research time on 10 November 2018 to 10 April 2019 at the Practice Field of the Binuang Agricultural Training Center, Binuang Village, Binuang District Tapin Regency, South Kalimantan Province. natural PGR treatment, and fertilizing Plant Supplements. The results of the study show that nutrition treatment, planting time and pollination arrangements, resulting in synchronization of the 1st crop pollination with the 2 nd crop is able to realize more than 2 cots corn plants, with a harvest system of 3 times, namely harvesting baby corn, young corn and corn pipil / feed. Baby corn production 325-450 Kg / Ha; 15,000-20,000 young corncobs / Ha; and dry corn yield of 9.65 tons / Ha, the OpSiTongTif corn corn cultivation system is able to provide business benefits for farmers amounting to Rp.26.750,000 / Ha / season with a $B / C$ ratio of 1,68. This system is also able to control the price of corn because farmers do not only produce pipil corn but produce baby corn and young corn with year-round production distribution.
\end{abstract}

Keyword:

Corn (Zea mays L);

Design of Planting Time Difference;

OpSiTongTif pattern;

Pollination;

Suplement Plants and $Z P T$;

\begin{abstract}
Kata Kunci:
\section{ABSTRAK}

Kajian ini mencoba untuk mengimplementasikan konsep optimalisasi nutrisi, polinasi, disain tanam, dan harmonisasi pasar.

Disain Tanam Beda Kaji widya ini membahas tentang manajemen pengelolaan nutrisi, optimalisasi tongkol dan polinasi, pengelolaan disain Waktu; tanam dan terwujudnya pasar yang sehat dan harmonis. Data dikumpulkan dari data primer (hasil penelitian pendahuluan riset ke-1 hingga riset ke- 6) dan data sekunder . Data primer diperoleh dari hasil penelitian 1 (sinkronisasi waktu polinasi

Jagung (Zea mays pada penanaman jagung beda waktu.) hingga penelitian ke-6 (optimalisasi mutu dan stabilisasi produksi). Data sekunder L); didukung dari data hasil jurnal, prosedding, makalah ilmiah dan teks buku tentang budidaya jagung, nutrisi, ZPT, Polinasi dan karakteristis tanaman Kelas Greamineae. Data pada kajian ke-7 menggunakan metode deskriptif siklus pertumbuhan dan perkembangan tanaman jagung pada beberapa waktu tanam yang berbeda umur 1, 2 hingga 3 minggu. Waktu penelitian Pola OpSiTongTif; pada tanggal 10 November 2018 hingga 10 April 2019 di Lahan Praktek Balai Besar Pelatihan Pertanian Binuang,

Polinasi; Kelurahan Binuang Kecamatan Binuang Kabupaten Tapin, Propinsi Kalimantan Selatan. Penerapan teknologi budidaya

Suplemen Tanaman dan ZPT; tanaman jagung sesuai teknologi rekomendasi spesifik lokalita dengan modifikasi waktu tanam/disain tanam, perlakuan ZPT alami, dan pemupukan Suplemen Tanaman. Hasil dari kajian menunjukkan bahwa perlakuan nutrisi, pengaturan waktu tanam dan polinasi, sehingga terjadi sinkronisasi polinasi tanaman ke-1 dengan tanaman ke-2 mampu mewujudkan tanaman jagung bertongkol lebih dari 2, dengan sistem panen 3 kali yaitu panen baby corn, jagung muda dan jagung pipil/pakan. Produksi baby corn 325-450 Kg/Ha; $15.000-20.000$ tongkol jagung muda/Ha ; dan hasil pipilan jagung kering 9,65 ton/Ha, Sistem buddiaya jagung pola OpSiTongTif mampu memberikan keuntungan usaha bagi petani sebesar Rp.26.750.000/Ha/musim dengan tingkat B/C ratio sebesar 1.68. Sistem ini juga mampu mengontrol harga jagung karena petani tidak produksi jagung pipil saja tapi menghasilkan baby corn dan jagung muda dengan distribusi produksi sepanjang tahun.
\end{abstract}




\section{PENDAHULUAN}

Peningkatan kebutuhan Jagung terus naik 7-9\%/tahun, baik bahan pangan dan industri turunannya yang makin beragam dan jumlahnya. Persaingan pasar dunia makin meningkat diera Pasar bebas 2020. Biaya produksi jagung nasional relatif meningkat 4,6-7,3\%/tahun; pada sisi lain harga pasar dunia relatif stagnan bahkan menurun $(-1,8 \mathrm{~s} / \mathrm{d}-2,6 \%)$. Tuntutan meningkatkan kesejahteraan petani makin meningkat seiring meningkatnya jumlah, jenis dan kualitas kebutuhan hidup.Target Swasembada Pangan soko guru Ketahanan Nasional. Kecenderungan degradasi kualitas lahan/lingkungan akibat intensifikasi pertanian. Makin tingginya resiko berusaha di sektor pertanian akibat perubahan iklim (ragam OPT, stress fisiologis, cekaman lingkungan ekstrem).

Kajian ini untuk mengimplementasikan konsep optimalisasi nutrisi, polinasi, disain tanam, dan harmonisasi pasar. Kajian ini diharapkan dapat menjawab waktu terjadi sinkronisasi polinasi bunga jantan (benangsari/manggar) dengan bunga betina (tongkol) dan prasyarat terjadinya proses polinasi secara optimal.

Kendala yang sering dihadapi dalam produksi benih hibrida jagung adalah pembungaan tetua jantan dan betina yang tidak bersamaan. Apabila hal ini terjadi selama proses pemuliaan maka perakitan varietas akan terhambat. Ngugi et al. (2013) melaporkan bahwa antesis tasel pada galur inbred terjadi 2.7-4 hari sebelum rambut tongkol muncul. Oleh karena itu teknologi pengelolaan serbuk sari dapat menjadi salah satu solusi untuk mengatasi ketidak-tersediaan serbuk sari ketika dibutuhkan. Teknik penyimpanan serbuk sari yang dapat mempertahankan viabilitasnya sepanjang mungkin akan bermanfaat bagi pengembangan jagung hibrida. Handayani (2014) melaporkan bahwa kombinasi perlakuan NPK (Ponskha) $600 \mathrm{~kg}$ ha-1 dengan boron $3 \mathrm{~kg}$ ha-1 pada tetua jantan jagung hibrida Bima
3 dapat meningkatkan jumlah spika per tasel, panjang spika, serta menghasilkan serbuk sari dengan viabilitas mencapai $>95 \%$ (metode pewarnaan $\mathrm{I} 2 \mathrm{KI}$ ). Meena (2010) menyatakan bahwa boron berperan dalam perkecambahan serbuk sari, proses pembungaan dan pembuahan. Atique-urRehman et al. (2014) menambahkan bahwa perlakuan priming benih padi dengan 0.1 $\mathrm{mM}$ boron, aplikasi boron pada tanah dengan dosis $1 \mathrm{~kg}$ ha-1, dan aplikasi di daun pada konsentrasi $200 \mathrm{mM}$ boron dapat meningkatkan fertilitas malai padi dari 3.16\% menjadi masing-masing 3.39\%, $3.4 \%$, dan $3.19 \%$. Teknik budidaya yang dapat meningkatkan produksi dan viabilitas serbuk sari jagung akan menunjang pengelolaan serbuk sari. Serbuk sari jagung mempunyai periode viabel yang pendek dan sensitif terhadap desikasi dan dehidrasi. Menurut Almeida et al. (2011) serbuk sari jagung yang dikeringkan menggunakan silika gel selama 48 jam kemudian disimpan pada suhu $-20{ }^{\circ} \mathrm{C}$ menghasilkan perkecambahan yang lebih tinggi (72\%) jika dibandingkan dengan serbuk sari yang dikeringkan menggunakan $\mathrm{CaC} 12 \mathrm{H} 2 \mathrm{O}$ (57\%) setelah 30 hari simpan. Hasil penelitian tersebut menunjukkan bahwa tantangan pengelolaan serbuk sari jagung bukan hanya mencari metode penyimpanan yang dapat memperpanjang periode viabel tetapi juga dapat menggambarkan potensi serbuk sari yang sudah disimpan. Pemupukan NPK tidak mempengaruhi pertumbuhan vegetatif dan perkembangan organ reproduktif, kecuali jumlah spika per tasel. Sementara aplikasi boron meningkatkan tinggi tanaman, tetapi tidak mempengaruhi jumlah daun dan perkembangan organ reproduktif. Namun demikian pemupukan NPK sampai dosis $900 \mathrm{~kg}$ ha-1 tidak meningkatkan pertumbuhan tanaman sebagaimana ditunjukkan oleh tinggi tanaman dan jumlah daun yang tidak bertambah. Data penelitian menunjukkan bahwa tinggi tanaman dan jumlah daun tak berpengaruh nyata. Pengaruh ti- 
dak langsung dengan pertumbuhan normal (optimal) akan mendukung proses polinasi dengan tassel, spikelete yang sehat dan berenergi untuk mengawini bunga betina yang sel telur berada pada tongkol jagung, dengan bantuan rambut ramput pada tongkol jagung inilah sel jantan melalui pipa rambut akan sampai di sel telur. Pemberian Pupuk seimbang NPK 16-16-16 sebesar $550-750 \mathrm{Kg} / \mathrm{Ha}$, yang di mix langsung dari pupuk tunggal; $150-250 \mathrm{Kg}$ bubuk Biochar dan ZPT alami dibuat sendiri dari $25 \mathrm{ml}$ SUPTAN dan larutan 1 butir telur, yang tepat akan mendorong peningkatan produksi jagung melalui proses pertumbuhan dan perkembangan proporsioanl untuk mendukung proses polinasi yang optimal, dilanjutkan proses pengisian biji pada kondisi air status kapasitas lapang optimal dengan pengawalan pengendalian Hama dan Penyakit khususnya penyakit bulai (downy mildew) dan Hama Ulat Grayak (Agrotis sp) (Budiono, 2014;2015;2017; dan 2018). Pemupukan NPK sampai dosis $900 \mathrm{~kg}$ ha-1 tidak meningkatkan panjang spika dan jumlah spikelet pertasel, tetapi meningkatkan jumlah spika per tasel dari rata-rata 9.3 menjadi 10.7 ( $\pm 10 \%)$ (Tabel 1). Peningkatan organ reproduktif melalui pemupukan diduga merupakan pengaruh tidak langsung dari peningkatan pertumbuhan tanaman. Pertumbuhan tanaman yang tidak meningkat menyebabkan tidak terjadi peningkatan panjang spika dan jumlah spikelet per tasel, serta peningkatan jumlah spika pertasel yang kecil. Penelitian Handayani (2014) pada tanaman yang sama menunjukkan bahwa pupuk NPK pada dosis $300 \mathrm{~kg}$ ha-1 dapat meningkatkan pertumbuhan tanaman (tinggi tanaman dan jumlah daun), namun peningkatan organ reproduktif sangat kecil sebagaimana ditunjukkan oleh jumlah spikelet per tasel yang meningkat dari 93.5 menjadi 95.3 buah $(1.9 \%)$. Peningkatan satu spika per tasel (dari 9.3 menjadi 10.7) dapat diartikan sebagai peningkatan jumlah serbuk sari yang dihasilkan, karena dalam satu spika terdapat sekitar 108 spikelet. Handayani (2014) melaporkan bahwa satu spikelet tetua jantan jagung varietas Bima 3 (Mr14) menghasilkan rata-rata 13.140 butir serbuk sari. Dengan demikian diperkirakan peningkatan satu spika setara dengan peningkatan jumlah serbuk sari sekitar 1.3 juta butir. Peningkatan jumlah serbuk sari tersebut akan bermanfaat jika dipanen dan disimpan untuk dapat digunakan ketika diperlukan. Dosis boron sampai $6 \mathrm{~kg}$ ha-1 hanya berpengaruh terhadap tinggi tanaman tetapi tidak berpengaruh terhadap jumlah daun dan perkembangan organ reproduktif. Penambahan boron di atas $3 \mathrm{~kg}$ ha- 1 cenderung menurunkan perkembangan organ reproduktif sebagaimana ditunjukkan oleh jum-lah spikelet per tasel. Dosis boron 4.5 dan $6 \mathrm{~kg}$ ha-1 menghasilkan tasel yang lebih kecil dengan dinding spikelet yang lebih tebal dan kompak. Menurut (Tahir et al., 2012), boron berperan dalam sintesi dinding sel. Kandungan boron yang tinggi menyebabkan penebalan dinding sel sehingga pembentukan spika dan spikelet terhambat. Lordkaew et al. (2011) menambahkan bahwa jagung hibrida NS72 yang diberi boron $20 \mu \mathrm{M}$ menghasilkan anter yang lebih tebal dan kandungan boron di tasel lebih tinggi dibandingkan tanaman tanpa pemberian boron. Tanpa pemberian NPK dan boron, viabilitas serbuk sari mencapai sekitar $87 \%$. Aplikasi boron $1.5 \mathrm{~kg}$ ha-1 tanpa pemupukan NPK menghasilkan viabilitas serbuk sari hingga $92.3 \%$. Sementara itu, peningkatan dosis NPK sampai $600 \mathrm{~kg}$ ha-1 tanpa pemberian boron menghasilkan viabilitas serbuk sari sampai $>90 \%$. Hal ini menunjukkan bahwa aplikasi pupuk NPK $600 \mathrm{~kg}$ ha-1 dapat berfungsi sebagai substitusi pupuk boron dalam meningkatkan viabilitas serbuk sari. Sementara itu, penambahan boron pada tanaman menguatkan dinding sel serta perkembangan sel serbuk sari selama mikrosporogenesis sehingga menghasilkan 
serbuk sari yang vigor. Hasil penelitian Lordkaew et al. (2011) $20 \mu \mathrm{M}$ menghasilkan perkecambahan serbuk sari yang lebih tinggi (19.3\%) dibandingkan tanaman tanpa boron (5.5\%). Selain itu, pemberian boron pada konsentrasi $20 \mu \mathrm{M}$ menghasilkan antera dengan dinding yang lebih tebal dibandingkan tanaman tanpa boron. Tanaman tanpa boron menghasilkan antera mengkerut dan serbuk sari kosong tanpa sitoplasma. Pemupukan NPK $600 \mathrm{~kg}$ ha-1 bersama dengan boron $3 \mathrm{~kg}$ ha-1 meningkatkan viabilitas serbuk sari tetua jantan jagung hibrida Bima 3 dari 89.6\% menjadi $99.3 \%$ menggunakan pewarna I2 KI (Handayani, 2014). Proses produksi benih jagung memerlukan serbuk sari dengan viabilitas tinggi untuk menjamin keberhasilan dalam penyerbukan. Serbuk sari yang viabel akan mampu membuahi sel telur dengan cepat. Kombinasi pemupukan NPK $900 \mathrm{~kg}$ ha-1 dan boron 6 $\mathrm{kg}$ ha-1 mampu menghasilkan viabilitas paling tinggi sehingga digunakan dalam produksi serbuk sari untuk disimpan dan kemudian digunakan dalam penyerbukan untuk produksi benih hibrida. Serbuk sari segar menghasilkan bobot benih per tongkol dan bobot benih per butir yang paling tinggi. Secara umum pembentukan benih dari penyerbukan dengan serbuk sari yang telah disimpan sangat rendah dibandingkan Penyerbukan dengan serbuk sari yang telah disimpan 1-3 MSS menghasilkan jumlah benih per tongkol yang sangat rendah. Hal ini diduga daya berkecambah serbuk sari yang sudah menurun selama disimpan sehingga menyebabkan tabung serbuk sari gagal mencapai mikropil dan membuahi sel telur. Faktor lain yang menjadi penyebab rendahnya jumlah benih diduga karena faktor cuaca saat penyerbukan yang mempengaruhi keberhasilan pembuahan (fertilisasi). Menurut Kaihatu dan Watkaat (2015), jagung Bima 3 menghasilkan jumlah benih per tongkol sebesar 488.3 butir pada kondisi optimum. Sementara itu pada penelitian ini penyerbukan menggunakan serbuk sari segar menghasilkan jumlah benih per tongkol yang lebih rendah yaitu 234.3 butir. Hujan yang turun pada siang hari setelah penyerbukan pada pagi harinya diduga menurunkan viabilitas serbuk sari atau menyebabkan serbuk sari jatuh sehingga jumlah benih yang terbentuk rendah. Menurut Kapu dan Cosgrove (2010), penyerbukan pada tanaman jagung selesai dalam waktu 24-42 jam, sehingga hujan yang turun dalam 42 jam setelah penyerbukan berpotensi menyebabkan kegagalan penyerbukan. Selain itu, RH yang tinggi (83-91\%) selama penyerbukan menyebabkan viabilitas serbuk sari turun dimana menurut Luna et al. (2001) daya hidup serbuk sari jagung pada RH $>53 \%$ hanya bertahan selama 1-2 jam. serbuk sari segar. Pemupukan NPK $900 \mathrm{~kg}$ ha-1 meningkatkan jumlah spika per tasel dari 9.3 buah menjadi 10.7 buah. Aplikasi NPK $600 \mathrm{~kg}$ ha-1 atau dosis boron $1.5 \mathrm{~kg}$ ha-1 dapat meningkatkan viabilitas serbuk sari jagung.

\section{METODOLOGI}

Lokasi di Kelurahan Binuang kecamatan Binuang Kabupaten Tapin jenis tanah alluvial dengan tekstur liat berpasir berdebu, warna tanah Munsell Soil Color Chart termasuk 5 BG yaitu coklat kelabu. Ketinggian $11 \mathrm{~m}$ dpl, curah hujan rata-rata berkisar antara 10,00-24,17 mm/hari dimana rata-rata curah hujan terendah pada Bulan September dan tertinggi pada Bulan April. Kelembaban udara dan temperatur dipengaruhi oleh ketinggian dan jarak dari permukaan air laut. Rata-rata temperatur udara sebesar $27,10^{\circ} \mathrm{C}$ pada Bulan Desember sampai dengan $28,70^{\circ} \mathrm{C}$. Rata-rata temperatur udara sebesar $27,10^{\circ} \mathrm{C}$ pada Bulan Desember sampai dengan $28,70^{\circ} \mathrm{C}$ pada Bulan Februari dan Maret. Suhu minimum $25{ }^{\circ} \mathrm{C}$ dan suhu maksimum $33.4{ }^{\circ} \mathrm{C}$. Ratarata kelembaban udara berkisar antara $67 \%$ pada Bulan Agustus sampai dengan 85\% pada Bulan Mei, November dan Desember 
(RPIJP,2015). Penentuan Lokasi lahan telah ditentukan, dengan penentuan petak kajian ditentukan secara acak, dengan dibantu alat undian nomor petak (1-27 petak) dengan kondisi relatif homogen lingkungannya selanjutnya sebagai populasi tanaman jagung dalam petak ada 30 tanaman. Sampling tanaman dalam petak yang akan diobservasi ditentukan 10 tanaman. Disain kajian dimulai dengan merumuskan masalah yaitu a. waktu yang tepat untuk perlakuan OpSiTongTif (sinkronisasi waktu polinasi tanaman pertama dan tanaman kedua dengan waktu perlakuan OpSiTongTif). b.Prasyarat kondisi yang harus dipenuhi untuk terjadinya OpSiTongTif; pelaksanaan teknik budidaya jagung pola OpSiTongTif; Observasi sesuai prosedur baku yang ada terhadap waktu munculnya akar adventive, bunga jantan dan betina; deskripsi proses terjadinya polinasi (perubahan rambut bunga betina, malai bunga jantan dan prosentase terjadi polinasi); menganalisis hasil observasi dan terakir menyimpulkan. Metode yang digunakan dalam kajian ini adalah metode deskriptif dilakukan untuk mendapatkan gambaran proses dan peluang optimalisasi produksi jagung. Bahan yang diperlukan meliputi Jagung Bisi 22, SUPTAN (Suplemen Tanaman yang dibuat dari campuran 1 it air +BMT 50ml+ Bislamad 1-3ml), Pupuk Urea, NPK, Obat, biochar, Pestisida, Irigasi, dan Bahan Pendukung. Alat Cangkul, sabit, timba, gelas ukur, handsprayer, timbangan, drum plastik biru, dan ATK. Definisi operasional dirumuskan sebagai berikut: 1) Penerapan budidaya pola OpSiTongtif. 2) Praktik menstimulus berkembangnya akar adventive dan bunga betina jagung. 3) Praktik Sinkronisasi waktu tanaman I dan tanaman susulan (II). Instrumen Penelitian menggunakan obser-vasi untuk pengamatan serta pencatatan dengan sistematik fenomenafenomena yang dikaji. Menurut Notoatmodjo (2010) instrumen penelitian adalah alat-alat yang akan digunakan untuk mengumpulkan data, instrumen kajian ini antara lain formulir observasi. Observasi menjadi salah satu metode pengumpulan data dengan mengamati atau meninjau secara cermat dan langsung di lokasi penelitian untuk mengetahui kondisi yang terjadi dalam kajian. Teknik observasi sesuai standar yang ditentukan mulai tahap menentukan lokasi, kapan, objeknya apa, lakukan survay awal, mengumpulkan referensi terkait, susun poin kajian secara umum, siapkan instrumen kajian alat tulis dan kamera, mengumpulkan fakta dan data, dan mencatat hasil observasi. Pengumpulan Data jenis kuantitatif berdasarkan hasil observasi diperoleh nilai (besaran) hasil penghitungan dan pengukuran terhadap parameter waktu munculnya akar adventive, bunga jantan dan betina; jumlah biji dalam tongkol, jumlah tongkol produktif dalam hasil panen baby corn, jagung muda dan jagung tua (pipil). Uraian proses terjadinya polinasi (perubahan rambut bunga betina, malai bunga jantan) dan akar adventive sebagai data pendukung dengan bukti dokumentasi dengan panduan observasi yang ada. Teknik Pengolahan Data: persiapan, pelaksanaan, pengolahan data, penafsiran data. Prosedur Penelitian Persiapan, pelaksanaan dan pelaporan.

\section{HASIL DAN PEMBAHASAN}

\section{Tinggi Tanaman (cm)}

Penelitian pendahuluan menginformasikan bahwa dengan pemupukan yang seimbang dengan dosis $550-750 \mathrm{Kg}$ NPK $+150-250 \mathrm{Kg}$ Bubuk Biochar, keragaman hara dari pupuk organik, waktu tepat, dan cara tepat dengan diikuti pemberian ZPT alami dari SUPTAN $25 \mathrm{ml}+$ larutan telur $75 \mathrm{ml}$ setiap tangki 14-17 lt dengan didukung cuaca yang mendukung dan perlakuan OpSiTongTif secara tepat dapat meningkatkan potensi tongkol produktif (Budiono, 2014; 2015; 2017; dan 2018). Pemupukan NPK sampai dosis $900 \mathrm{~kg}$ ha1 tidak meningkatkan panjang spika dan jumlah spikelet pertasel, tetapi meningkatkan jumlah spika per tasel dari rata-rata 
9.3 menjadi $10.7( \pm 10 \%)$. Peningkatan organ reproduktif melalui pemupukan diduga merupakan pengaruh tidak langsung dari peningkatan pertumbuhan tanaman. Pertumbuhan tanaman yang tidak meningkat menyebabkan tidak terjadi peningkatan panjang spika dan jumlah spikelet per tasel, serta peningkatan jumlah spika pertasel yang kecil. Peningkatan satu spika per tasel (dari 9.3 menjadi 10.7) dapat diartikan sebagai peningkatan jumlah serbuk sari yang dihasilkan, karena dalam satu spika terdapat sekitar 108 spikelet. Handayani (2014) melaporkan bahwa satu spikelet tetua jantan jagung varietas Bima 3 (Mr14) menghasilkan rata-rata 13.140 butir serbuk sari. Dengan demikian diperkirakan peningkatan satu spika setara dengan peningkatan jumlah serbuk sari sekitar 1.3 juta butir. Peningkatan jumlah serbuk sari tersebut akan bermanfaat jika dipanen dan disimpan untuk dapat digunakan ketika diperlukan.

Berdasarkan hasil kajian ini diperoleh informasi pemupukan NPK/Ponskha $550-750 \mathrm{Kg}+150-250 \mathrm{Kg}$ Bubuk Biochar dengan dukungan ZPT alami SUPTAN 25 $\mathrm{ml}+$ larutan telur $75 \mathrm{ml}$ dengan waktu dan cara pemberian sesuai SOP Budidaya Jagung Pola OpSiTongTif mampu memberikan tongkol produktif yang dipanen bentuk jagung pipil $50 \%$ dipanen 2 tongkol dan $50 \%$ dipanen 1 tongkol. Jagung muda dipanen 1 tongkol muda/tanaman dan baby corn dipanen 2 babycorn/tanaman. Sebagaimana pada gambar 2 (Umur/HST pertama).

Adanya kejadian beberapa kasus tongkol hampa (tak berbiji), disebabkan oleh beberapa hal,antara lain:

1. Kegagalan sinkronisasi waktu pertanaman pertama dengan pertanaman kedua, mengingat waktu polinasi berkisar 5-10 hari. Idialnya kedua tanaman tersebut ada keselarasan munculnya bunga jantan dan betina sehingga probabilitas terjadinya polinasi tahap II bisa diatas $30 \%$ pada kasus kejadian beberapa ada yang mengalami kegagalan polinasi mencapai lebih $70 \%$. Kondisi ini dipicu oleh curah hujan tinggi saat waktu proses polinasi, yaitu 48 jam sesuadahnya. Kecepatan angin yang membantu polinasi dibawah 1 Knot, ididalnya 1-3 Knot. Suhu udara berkisar 28 - 33oC, Lahan mengalami kekeringan (dibawah kapasitas lapang), pelepah daun yang menua sehingga tidak efisien untuk mendukung pasokkan hasil fotosintetis.

2. Pengawalan Hama Ulat Grayak dan Penyakit Bulai perlu ditangani sejak dini, mulai perlakuan benih hingga umur $40 \mathrm{HST}$, diuahakan hingga selesai pengisian biji yaitu umur 75 HST.

3. Perlu adanya kajian perbedaan karakteristik lokasi terkait cuaca, kesesuain lahan, dan komponen yang berpengaruh terhadap pertumbuhan dan produksi jagung secara spesifik lokalita.

Perlakuan Optimalisasi Produksi Tongkol Produktif (OpSiTongTif) yang menentukan keberhasilan target kajian ini adalah:

1. Menentukan waktu pertanaman pertama dan pertanaman kedua (10-15 HST pertama),diperlukan ujicoba skala kecil dulu.

2. Memperhitungkan munculnya akar adventive dan tongkol susulan pada pertanaman pertama, dengan distimulus larutan SUPTAN dan larutan telur.

3. Pembuatan larutan SUPTAN dari 1lt air +suplemen Bio Master Tani 50 ml+Bislamad 1-3 ml

4. Penyemprotan larutan SUPTAN pada akar adventive yang sudah keluar dipangkal batang dilanjutkan di bumbun agar berkembang menjadi akar serabut yang aktif menyerap air dan nutrisi. 
Tabel 1: Pengaruh Berbagai Dosis Pemberian Pupuk NPK (Ponskha) dan Urea (2:1) Terhadap Peluang Tumbuh dan Produktifnya Tongkol (Bunga betina); Jagung BISI -22 di Lahan Praktek BBPP Binuang

\begin{tabular}{|c|c|c|c|c|}
\hline \multirow{2}{*}{ Nomor } & $\begin{array}{c}\text { Dosis Pemberian Ponskha } \\
(\mathrm{g} / \mathrm{tanaman})\end{array}$ & $\begin{array}{c}\text { Tongkol Pakan } \\
\text { (Pipil kering); } \\
\text { (tongkol/tan) }\end{array}$ & $\begin{array}{c}\text { Tongkol Muda } \\
\text { (tongkol/tan) }\end{array}$ & $\begin{array}{c}\text { Baby corn } \\
\text { (Janten); } \\
\text { (tongkol/tan) }\end{array}$ \\
\hline 1 & $2.5(137.5 \mathrm{Kg} / 55.000 \mathrm{tan} / \mathrm{Ha})$ & 1 & - & - \\
\hline 2 & $5.0(275.0 \mathrm{Kg} / 55.000 \mathrm{tan} / \mathrm{Ha})$ & 1 & - & 2 \\
\hline 3 & $7.5(412.5 \mathrm{Kg} / 55.000 \mathrm{tan} / \mathrm{Ha})$ & 1 & 1 & 1 \\
\hline 4 & $10.0(550.0 \mathrm{Kg} / 55.000 \mathrm{tan} / \mathrm{Ha})$ & $1,3(1-2)$ & 1 & 2 \\
\hline 5 & $12.5(687.5 \mathrm{Kg} / 55.000 \mathrm{tan} / \mathrm{Ha})$ & $1,5(1-2)$ & 1 & 1 \\
\hline \multicolumn{5}{|r|}{ SEMUA DIPERLAKUKAN OpSiTongTif } \\
\hline
\end{tabular}

(Sumber:Budiono, 2019)

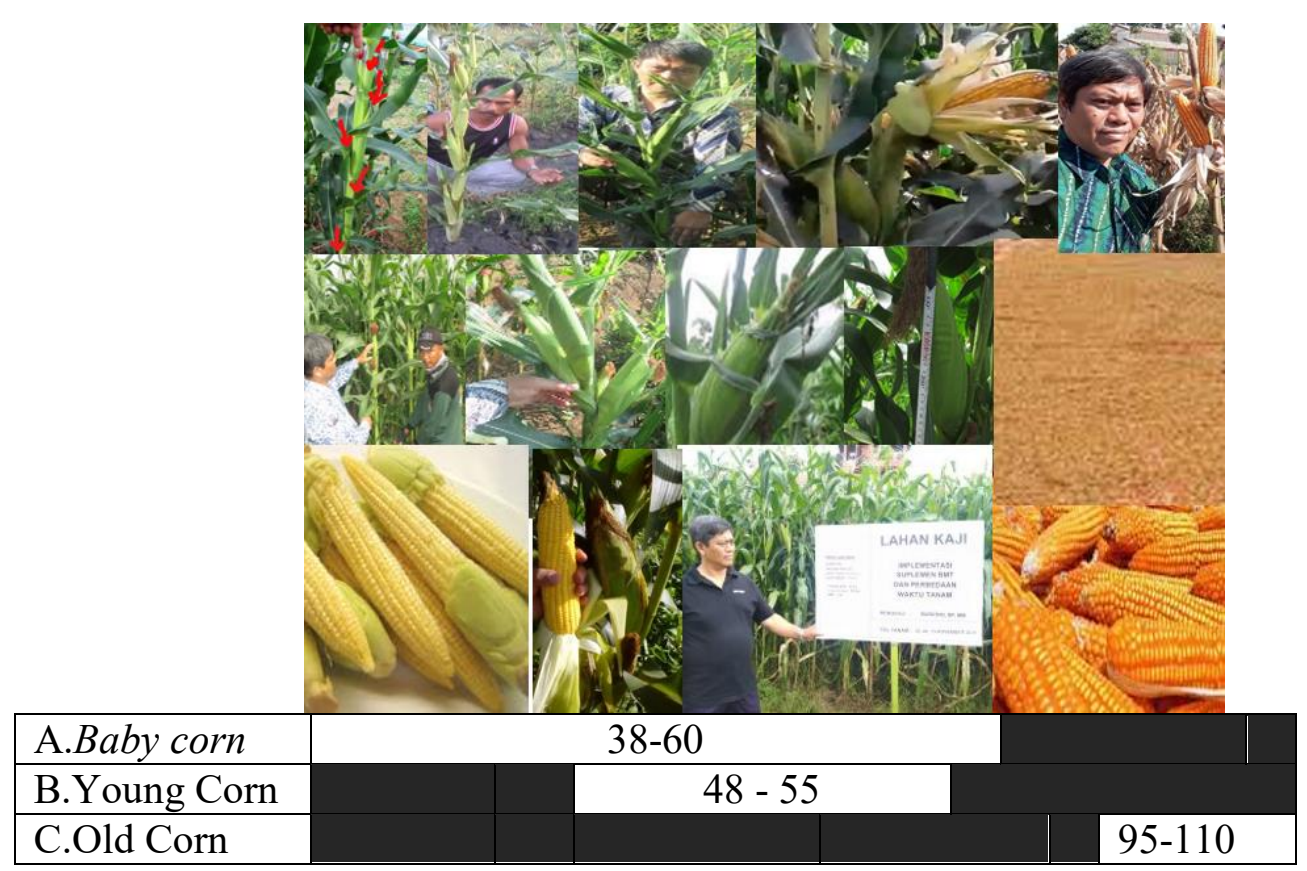

Gambar 2: Tongkol Produktif 1-2 baby corn (A); 1-2 tongkol muda(B) ; dan tongkol $\operatorname{pipil}(\mathrm{C})$

Biochar plus merupakan pupuk organik alternatif yang merupakan bubuk atau bahkan nano partikel carbon yang diproduksi melalui proses pirolisis, yangt telah diperkaya dengan unsur hara makro, mikro, asam asam organik dan bahan biokatalis. Keunggulannya mudah diserap oleh tanaman dan mampu membantu mengabsorsi persenyawaan nitrogen, kation kation sebagai penggerak metabolisme tanaman. Air kelapa merupakan sumber kation $\mathrm{K}, \mathrm{Ca}$, dan sitokine. Telur sebagai bahan Zat Perangsang Tumbuh mengandung asam asam amino yang mampu langsung diserap melalui stomata. Sebagai sumber energi tinggi dan pre-fitohormon yang berkolaborasi dengan SUPTAN mampu menstimulus akar adventive yang pasif menjadi aktif menyerap air dan nutrisi membantu menyuplai kebutuhan pertumbuhan dan perkembangan tanaman. 


\section{KESIMPULAN}

1. Potensi jagung bertongkol lebih dari 2/tanaman, dengan prasyarat terpenuhinya keseimbangan nutrisi, cuaca dan ZPTsesuai kebutuhannya.

2. Potensi untuk panen lebih dari 1 kali dalam satu tanam/musim, yaitu umur 4855 HST pertama panen jagung muda; umur 53-60 HST pertama panen baby corn dan terakhir umur 95-110 HST pertama panen tongkol jagung pakan (pipil).

3. Keseimbangan nutrisi sebaiknya ikuti spesifik lokal, sebagai informasi awal diperlukan 550-700 Kg NPK, 150-250 Kg BIOCHAR bubuk, ZPT alami dosis telur $1+50$ cc Bio Master Tani/tanki 1417 lt. NPK yang dimaksud merupakan pupuk hasil mixer pupuk tunggal Urea, SP-36 dan $\mathrm{KCl}$ sehingga menghasilkan NPK atau Ponskha. Biochar sudah dihaluskan dalam bentuk bubuk atau diusahakan nano biochar.

4. Mengeliminasi seoptimal dari dampak cuaca khususnya intensitas curah hujan saat proses polinasi. Kecepatan angin standar 1-3 Knot, untuk memudahkan distribusi bunga jantan (benangsari) secara alami oleh angin, peran petani mengatur jarak tanam idial $75 \times 20 \mathrm{~cm}$ dan antar bedeng 50-60 cm. Kelembaban idial untuk proses polinasi sebesar 70-80\%. Kapasitas lapang lahan khususnya saat pertumbuhan dipercepat umur 7-40 HST pertama; pengisian biji tongkol umur 38 - 75 HST pertama. Sebaliknya setelah umur 75 HSThingga waktu panen lahan tidak memerlukan pengairan lagi, justru disaat musim hujan saluran drainase harus lancar.

5. Waktu polinasi antar kelompok tanaman jagung beda tanam 10-15 hari, mengingat kesempatan untuk terjadinya polinasi hanya 5-10 hari. Untuk mengurangi resiko sebaiknya tanaman ke-2 ditanam dalam bentuk bibit semai jagung umur 5-7 hari. Perlakuan OpSiTongTif (optimalisasi Produksi Tongkol Produktif) saat akar adventive di ruas batang bawah mulai tumbuh $2-5 \mathrm{~cm}$, dengan penyemprotan larutan telur dan SUPTAN (1 telur dikocok +air 100ml diaduk) $+25 \mathrm{ml} \mathrm{SUPTAN} \mathrm{(BMT} 50 \mathrm{ml}$ $+1-2$ cc Bislamad) untuk 1 tangki 14-17 lt.

\section{UCAPAN TERIMA KASIH}

Terima kasih kepada :

1. Kepala Balai Dr. Yulia Asni Kurniawati, M.Si dan Segenap kolega di UPT BBPP Binuang atas dukungannya.

2. Segenap keluarga besar di Kota Malang atas dukungan morill

3. Segenap Penyuluh Pertanian di BPP Pangkalan Banteng, Kabupaten Kotawaringin Barat atas dukungan dilapangan selama kajian.

4. Segenap Petani Madani Kota Batu atas dukungan dilapangan selama kajian.

\section{SUMBER DANA PENELITIAN}

Sponsor Balai Besar Pelatihan Pertanian Binuang, BPPSDMP,Kementan RI

\section{DAFTAR PUSTAKA}

Budiono, 2014. Pengaruh pemberian Suplemen ZPT BMT pada Akar Adventif Tanaman Jagung (Zea mays L.) pada Lahan Kering Desa Bumiaji Kecamatan Bumiaji Kota Batu. Dokumen Makalah Ilmiah.

Budiono,2015. Pengaruh pemberian Suplemen ZPT BMT pada Akar Adventif Tanaman Jagung (Zea mays L.) pada Lahan Kering Desa Mawarbang Kecamatan Kedungpring Kabupaten Lamongan. Dokumen Makalah Ilmiah.

Budiono,2015. Pengaruh pemberian Suplemen ZPT BMT pada Akar Adventif Tanaman Jagung (Zea mays L.) pada Desa Sungai Sebrang, Kecamatan Kumai, Kabupaten 
Kotawaringin Barat. Bappenas International Conference on Best Development Practices and policies.Jakarta.Hal.5-15

Budiono,2017. Pengaruh pemberian Suplemen ZPT BMT pada Akar Adventif Tanaman Jagung (Zea mays L.) pada lahan praktek BBPP Binuang. Makalah Ilmiah.Lokakarya Inovasi Penelitian Daerah.Badan Penelitian dan Pengembangan Daerah Propinsi Kalimantan Barat

Budiono, 2018. Pengaruh pemberian Suplemen ZPT BMT pada Akar Adventif Tanaman Jagung (Zea mays L.) pada lahan praktek BBPP Binuang. Seminar nasional :Pengelolaan Potensi Lokal Spesifik.Fakultas Pertanian, Universitas Lambung Mangkurat.Banjarbaru

Handayani, D.P. 2014. Peningkatan viabilitas serbuk sari jagung dengan pemupukan NPK dan boron, dan pemanfaatannya dalam produksi benih hibrida. Tesis. Sekolah Pascasarjana. Institut Pertanian Bogor.Bogor.

Harliani, E.N., E.R. Palupi, D.S. Wahyudin. 2014. Potensi penyimpanan serbuk sari dalam produksi benih hibrida mentimun (Cucumis sativus L.) varietas KE014. J. Hort. Indonesia 5:104117.

Hermawati, S. 2015. Pengeringan dan penyimpanan serbuk sari dalam produksi benih cabai hibrida IPB. Tesis.Sekolah Pascasarjana. Institut Pertanian Bogor. Bogor.

Huang, L., J. Pant, B. Dell, R.W. Bell. 2000. Effects of boron deficiency on anther development and floret fertility in wheat (Triticum aestivum L. 'Wilgoyne'). Ann. Bot. 85:493500 .

Kaihatu, S.S., F. Watkaat. 2015. Kajian adaptasi beberapa varietas unggul jagung di kabupaten Maluku Barat Daya (MBD). Agric 27:8-14.

Kapu, N.U.S., D.J. Cosgrove. 2010. Changes in growth and cell wall extensibility of maize silks following pollination. J. Exp. Bot. 61:40974107.

Ngugi, K., J. Cheserek, C. Muchira, G. Chemining'wa. 2013. Anthesis to silking interval usefulness in developing drought tolerant maize. J. Renew. Agric. 1:84-90. Palupi

Sebayang, H.T., A. Suryanto, T.I.D. Kurnia. 2010. Pengaruh pemberian kayu apu (Pistia stratiotes L.) dan dosis pupuk N, P, K pada pertumbuhan dan hasil padi sawah (Oryza sativa L.). J. Agron. Indonesia 38:192-198.

Tahir, M., A. Ali, F. Khalid, M. Naeem, N. Fiaz, M. Waseem.2012. Effect of foliar applied boron application on growth, yield and quality of maize (Zea mays L.). Pak. J. Sci. Indust. Res. 55:117-121 